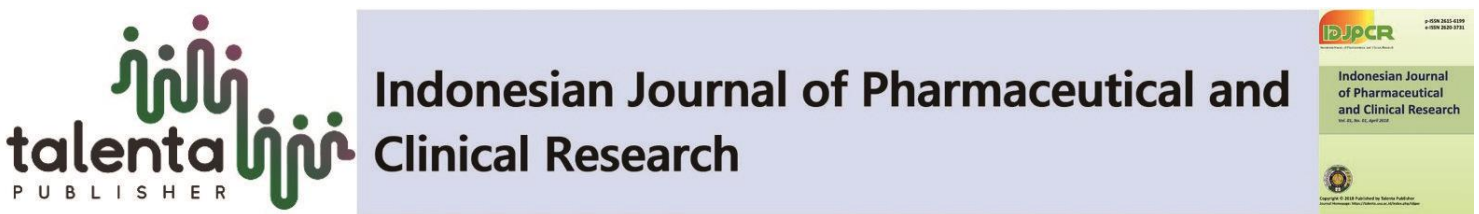

\section{Analgesic Activity of Ethanol Extract of Temu Giring Rhizome (Curcuma heyneana Val \& Zijp) in Mice}

\author{
Marianne $^{*}$, Khairunnisa, Wilda \\ Department of Pharmacology, Faculty of Pharmacy, Universitas Sumatera Utara, Medan 20155, \\ Indonesia
}

\begin{abstract}
Temu giring (Curcuma heyneana Val \& Zijp) is a traditional medicinal plant that is believed in community as an analgesic. The objective of this research was to determine the analgesic activity of the $C$. heyneana rhizome by using infra red (IR) thermal induction method in mice. Mice were divided into 7 groups. Group 1 served as negative control, group 2,3,4,5 served as treatment groups which were given ethanol extract of $C$. heyneana rhizome at dose of $5,25,125$, and $625 \mathrm{mg} / \mathrm{kg}$ respectively, group 6 and 7 served as comparable groups, given antalgin $65 \mathrm{mg} / \mathrm{kg}$ and morphine sulphate $1.3 \mathrm{mg} / \mathrm{kg}$, respectively. The observation has been done, pain stimulus of mice by exposing to infra red (IR) every 10 minutes for 80 minutes. The data were analyzed by ANOVA at the significance level of $95 \%$. Ethanol extract of $C$. heyneana at the doses of 25, 125, and 625 $\mathrm{mg} / \mathrm{kg}$ had significant effect to reduce the pain compared to the negative control $(\mathrm{p}<0.05)$. Ethanol extract of $C$. heyneana rhizome at dose of $125 \mathrm{mg} / \mathrm{kg}$, had the same effect to antalgin $65 \mathrm{mg} / \mathrm{kg}(\mathrm{p} \geq 0.05)$, while the ethanol extract of $C$. heyneana at the dose of 625 $\mathrm{mg} / \mathrm{kg}$ had the same effect as morphine sulfate $1.3 \mathrm{mg} / \mathrm{kg}(\mathrm{p} \geq 0.05)$. It can be concluded that ethanol extract of $C$. heyneana rhizome has analgesic activity.
\end{abstract}

Keywords: temu giring, analgesic, Curcuma heyneana, rhizome

\begin{abstract}
Abstrak. Temu giring (Curcuma heyneana Val \& Zijp) adalah tanaman obat tradisional yang diyakini berkhasiat sebagai penghilang rasa nyeri. Tujuan dari penelitian ini adalah untuk membuktikan aktivitas analgesik dari rimpang $C$. heyneana dengan menggunakan metode induksi termal infra merah (IR). Mencit dibagi menjadi 7 kelompok. Kelompok 1 adalah kontrol negatif, kelompok 2, 3, 4 adalah kelompok perlakuan yang diberikan ekstrak etanol rimpang C. heyneana dengan dosis 5, 25, 125, dan $625 \mathrm{mg} / \mathrm{kg}$, kelompok 5 dan 6 adalah kelompok pembanding yang diberikan antalgin $65 \mathrm{mg} / \mathrm{kg}$ serta morfin sulfat $1,3 \mathrm{mg} / \mathrm{kg}$. Pengamatan meliputi daya tahan mencit untuk menahan nyeri yang ditimbulkan oleh paparan infra merah (IR) pada telapak kaki yang diinduksi setiap 10 menit dan berlangsung selama 80 menit. Data dianalisis dengan menggunakan ANOVA pada tingkat signifikansi 95\%. Ekstrak etanol C. heyneana pada dosis 25, 125, dan $625 \mathrm{mg} / \mathrm{kg}$ memiliki efek yang signifikan untuk mengurangi nyeri dibandingkan dengan kontrol negatif $(p<0,05)$. Pada dosis $125 \mathrm{mg} / \mathrm{kg}$, ekstrak etanol rimpang C. heyneana memiliki efek yang sama seperti antalgin $65 \mathrm{mg} / \mathrm{kg}(p \geq 0,05)$. Sedangkan ekstrak etanol C. heyneana pada dosis $625 \mathrm{mg} / \mathrm{kg}$ memiliki efek yang sama seperti morfin sulfat $1,3 \mathrm{mg} / \mathrm{kg}(p \geq 0,05)$. Dapat disimpulkan bahwa ekstrak etanol rimpang C. heyneana dosis 25, 125 dan $625 \mathrm{mg} / \mathrm{kg}$ memiliki aktivitas analgesik.
\end{abstract}

Kata kunci: temu giring, analgesik, Curcuma heyneana, rimpang

\footnotetext{
*Corresponding author at: Department of Pharmacology, Faculty of Pharmacy, Universitas Sumatera Utara, Medan 20155, Indonesia

E-mail address: marianne80@usu.ac.id
} 
Received 21 September 2018 | Revised 18 October 2018 | Accepted 26 November 2018

\section{Introduction}

NSAIDs or nonsteroidal anti-inflammatory drugs are the most common medicine as pain relief in the community. It is used to relieve symptoms of arthritis, sprains, headaches and other daily discomforts [1]. Long periode of NSAIDs utilization could increase its side effect such as gastrointestinal irritation, bleeding, blurred vision, and decreased kidney function [2]. Utilization of paracetamol in the long period could induce hypersensitivity reactions, blood disorders, and liver damage [3]. Opioid analgesics also have the potential effect in tolerance, dependence and addiction [4].

Herbal medicine treatment is currently popular as an alternative treatment to heal various disease including as pain reliefer. One of the herbal medicine that widely used by Indonesian people is temu giring (Curcuma heyneana Val \& Zijp). Empirically, local people use temu giring rhizome to treat various disease such as rheumatism, irregular menstruation, stomach aches, fever and as anthelmintic. Temu giring rhizome has various phytochemical properties of essential oils, starch, resin, fat, tannins, saponins, and flavonoids [5]. It is necessary to conduct research in determining analgesic activity of ethanol extract of temu giring (EETG). The purpose of this study was to determine the analgesic activity of the ethanol extract of temu giring on male mice using a infra red plantar test.

\section{Material and Method}

\subsection{Materials}

Temu giring rhizome was obtained from PT. Sumatera Busan, Deli Serdang, North Sumatra, Indonesia. Sodium Carboxymethyl Cellulose, distilled water were obtained from PT. Bratachem, Indonesia . Morphine sulfate and antalgin were obtained from PT. Kimia Farma, Indonesia.

\subsection{Animals}

Male mice of 3 months old were obtained from the Animal House of Faculty of Pharmacy Universitas Sumatera Utara. Mice were acclimatized for 2 weeks under standard laboratory conditions at room temperature condition $25-30^{\circ} \mathrm{C}$. The mice were fed with standard laboratory diet and allowed to drink water. The studies were carried out in accordance with the institutional ethical guidelines.

\subsection{Research Methods}

The research had obtained approval ethical clearance with No. 785 / KEPH-FMIPA / 2016. The extract was obtained by maceration method using ethanol $96 \%$. The analgesic test used a plantar test with infra red (IR). Mice were devided into 7 groups. Group 1 served as negative control, 
group 2, 3, 4, 5 served as treatment groups which were given ethanol extract of temu giring rhizome at dose of $5,25,125$, and $625 \mathrm{mg} / \mathrm{kg}$ respectively, group 6 and 7 served as comparable groups, given antalgin $65 \mathrm{mg} / \mathrm{kg}$ and morphine sulphate $1.3 \mathrm{mg} / \mathrm{kg}$, respectively. The observation had been done, included the pain stimulus of mice which exposed by infra red (IR) every 10 minutes for 80 minutes.

\subsection{Statistical Analysis}

Analysis of all results were performed using ANOVA. $P$ values for significance were set at 0.05 .

\section{Result and Discussion}

The results of analgesic activity of ethanol extract of temu giring rhizome by the infra red (IR) plantar test method can be seen in Figure 1.

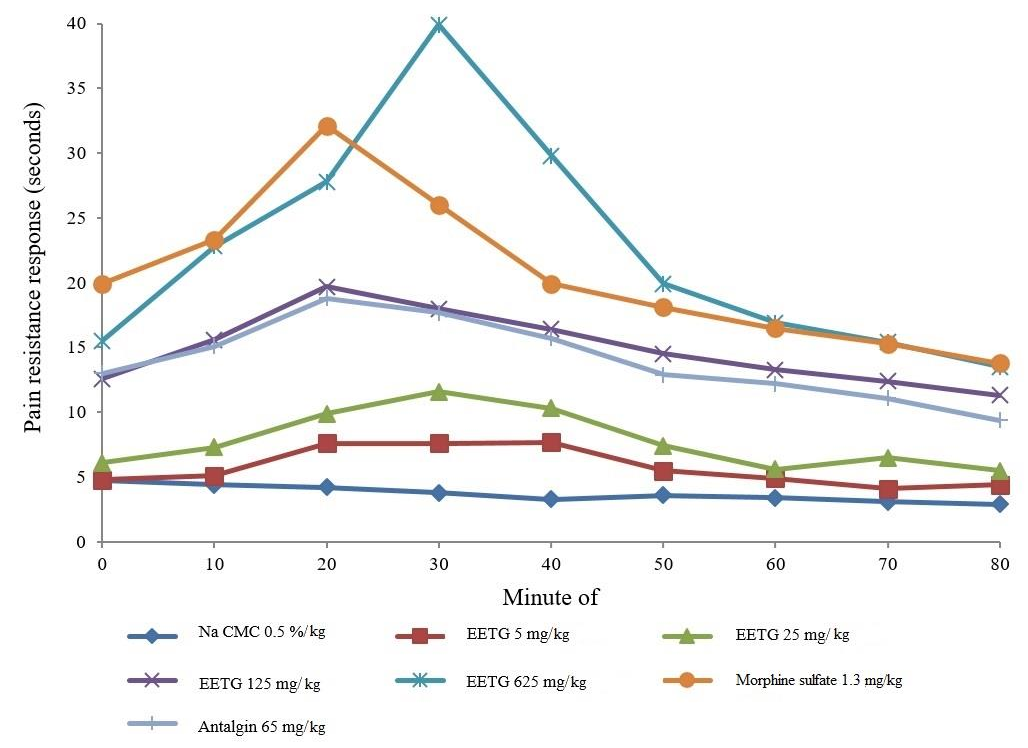

Figure 1. Analgesic effect ethanol extract of temu giring rhizome on mice induced by infra red (IR).

Figure 1 shows that negative control which only given a vesicle (sodium carboxymethyl cellulose), there was no analgesic effect when it exposed by infrared for 5 seconds, the mice appeared raise their legs. Ethanol extract at dose of $5 \mathrm{mg} / \mathrm{kg}$ showed no analgesic effect. Based on observations the mice were not able to resist pain induction, the condition of mice were same as to the negative controls. Dose of $25 \mathrm{mg} / \mathrm{kg}$, showed ability as pain reliefer to infra red compare to negative control group $(\mathrm{p}<0.05)$. However, the pain relief effect was not as strong as the antalgin and morphine groups $(\mathrm{p}<0.05)$.

Dose of $125 \mathrm{mg} / \mathrm{kg}$ were able as pain reliefer due to infra red induction, it had longer activity than the effect caused by dose of $25 \mathrm{mg} / \mathrm{kg}$ and showed similar effects with antalgin ( $p>0.05$ ) but not to morphine $(\mathrm{p}<0.05)$. Mice given a dose of $625 \mathrm{mg} / \mathrm{kg}$ showed the strongest analgesic effect and comparable with the analgesic effects of morphine ( $\mathrm{p} \geq 0.05)$. The plantar test method 
(Hargreaves method) was a appropiate model to determine peripheral response of thermal stimuli in animals.

The results showed that animals that had been given ethanol extract of temu giring rhizome were able to resist pain induction longer than animals that were not given an extract. Temu giring rhizome has secondary metabolite content of flavonoids. Previous research stated that flavonoids content in plants had an analgesic effect in mice [6,7]. Other studies stated that flavonoids were known to inhibit the formation of cyclooxygenase (COX) or lipooxygenase [8]. Temu giring rhizome also had curcuminoid content which were composed of curcumin, demethoxycurcumin and bismethoxycurcumin. Curcumin also had an effect in inhibiting the metabolism of arachidonic acid, cyclooxygenase, lipooxygenase and cytokines [9]. It was stated that curcumin significantly inhibited mRNA expression and COX-2, but not in COX-1 [9]. Cyclooxygenase (COX) is known as substances of pain mediators, phytochemical properties of temu giring could inhibit cyclooxygenase (COX) and it will reduce pain. In addition, curcumin also has a high selectivity to COX-2 which has lower side effect on gastrointetinal than non selective analgesics drug.

\section{Conclusion}

It can be concluded that the ethanol extract of temu giring rhizome at dose of 25,125 and 625 $\mathrm{mg} / \mathrm{kg}$ have analgesic effect.

\section{Acknowledgment}

The authors thanks to Faculty of Pharmacy, University of Sumatera Utara for supporting this research.

\section{REFERENCES}

[1] M. Hyllested, S. Jones, J. L. Pedersen, and H. Kehlet, "Comparative effect of paracetamol, NSAIDs or their combination in postoperative pain management: a qualitative review," British Journal of Anaesthesia, vol. 88, no. 2, pp. 199-214, Feb. 2002.

[2] I. Bjarnason, J. Hayllar, A. N. dre. J. Macpherson, and A. N. thon. S. Russell, "Side effects of nonsteroidal anti-inflammatory drugs on the small and large intestine in humans," Gastroenterology, vol. 104, no. 6, pp. 1832-1847, Jun. 1993.

[3] A. H. Gilani, K. H. Janbaz, and B. H. Shah, "Esculetin prevents liver damage induced by paracetamol and ccl4," Pharmacological Research, vol. 37, no. 1, pp. 31-35, Jan. 1998.

[4] T. J. Cicero, R. C. Dart, J. A. Inciardi, G. E. Woody, S. Schnoll, and A. Muñoz, "The Development of a Comprehensive Risk-Management Program for Prescription Opioid Analgesics: Researched Abuse, Diversion and Addiction-Related Surveillance (RADARS ${ }^{\circledR}$ )," Pain Medicine, vol. 8, no. 2, pp. 157-170, Mar. 2007.

[5] M. Aspollah Sukari, T. S. Wah, S. M. Saad, N. Y. Rashid, M. Rahmani, N. H. Lajis, and T.-Y. Y. Hin, "Bioactive sesquiterpenes from Curcuma ochrorhiza and Curcuma heyneana," Natural Product Research, vol. 24, no. 9, pp. 838-845, May 2010. 
[6] M. S. Ahmed, N. D. E. Tanbouly, W. T. Islam, A. A. Sleem, and A. S. E. Senousy, "Antiinflammatory flavonoids fromOpuntia dillenii (Ker-Gawl) Haw. flowers growing in Egypt," Phytotherapy Research, vol. 19, no. 9, pp. 807-809, 2005.

[7] M. Picq, S. L. Cheav, and A. F. Prigent, "Effect of two flavonoid compounds on central nervous system. Analgesic activity," Life Sciences, vol. 49, no. 26, pp. 1979-1988, Jan. 1991.

[8] Y. S. Chi, H. G. Jong, K. H. Son, H. W. Chang, S. S. Kang, and H. P. Kim, "Effects of naturally occurring prenylated flavonoids on enzymes metabolizing arachidonic acid", Biochemical Pharmacology, vol. 62, no. 9, pp. 1185-1191, Nov. 2001.

[9] S. Bengmark, "Curcumin, An Atoxic Antioxidant and Natural NFkB, Cyclooxygenase-2, Lipooxygenase, and Inducible Nitric Oxide Synthase Inhibitor: A Shield Against Acute and Chronic Diseases," Journal of Parenteral and Enteral Nutrition, vol. 30, no. 1, pp. 45-51, Jan. 2006. 